\title{
Study on Endophytic Fungi Associated with Moringa oleifera Lam. Collected from Lombok Island, West Nusa Tenggara
}

\author{
Indriati Ramadhani ${ }^{1, *}$, Hasnadiazahra Rohadi ${ }^{2}$, Yeni Yuliani ${ }^{1}$, and Muhammad Ilyas ${ }^{1}$ \\ ${ }^{1}$ Microbiology Division, Research Center for Biology, Indonesian Institute of Sciences (LIPI), \\ Indonesia \\ ${ }^{2}$ Faculty of Biology, Jenderal Soedirman University, Indonesia
}

\begin{abstract}
An assemblage of endophytic fungi was isolated from Moringa oleifera Lam. collected from Lombok island, West Nusa Tenggara Province, Indonesia. Fungal endophytes were isolated using surface sterilization methods with slight modification. Forty-six selected endophytic fungal strains were isolated from the leaves, petioles, and stems of M. oleifera. The fungal strains identification through morphological observation and ITS rDNA-based molecular analysis showed that fungal endophytes were associated with host plants belonging to the taxa Alternaria, Cladosporium, Colletotrichum (Glomerella), Corynespora, Curvularia (Cochliobolus), Fusarium, Mucor, Ochrocladosporium, Phomopsis (Diaporthe), and Trametes. In this study, endophytic Phomopsis dominating the obtained strains, whereas $26 \%$ (12/46) strains were isolated from host plant samples.
\end{abstract}

Keywords: endophytic fungi, fungal identification, fungal isolation, ITS rDNA, Moringa oleifera Lam.

*Corresponding author:

Cibinong Science Center, Jl. Raya Bogor Km. 46, Cibinong 16911, Indonesia

Tel. +62-21-8671356, Fax. +62-21-8671357

E-mail. indriatiramadhani@gmail.com

\section{Introduction}

Moringa oleifera Lam., widely known as 'drumstick tree', is one of the 'miracle tree' because all of its parts are widely used for nutritional and medicinal purposes. This plant is known to have beneficial properties including antioxidants, antibacterial, antifungal, anti-cholesterol, anti-inflammatory, anti-ulcer, pain relief, immunomodulatory, and wound healing (Fuglie, 1999; Hassan \& Ibrahim, 2013; Aminah et al., 2015). Moringa oleifera can associate with microorganisms that naturally live in plant tissues as beneficial symbionts and are able to live by forming colonies without endangering their hosts. These microorganisms, called endophytes, can be bacteria or fungi. However, endophytic fungi are more abundant than endophytic bacteria in nature (Tan \& Zou, 2001).

Endophytic fungi could be found in every part of the plant, such as leaf, stem, root, flower, fruit, and seed. Endophytic fungi can produce secondary metabolites that depend on their host plant. Those secondary metabolites protect the host plant itself and can act as antimicrobial and antivirus. Moreover, the use of secondary metabolites of endophytes could also reduce the overexploitation of medicinal plants as the source materials of drugs and the production cost of medicines (Dhanalakhsmi et al., 2013; Kursia et al., 2018).

Exploring endophytic fungi from plants will be useful in finding endophytic fungi that possess specific and unique properties. Endophytic fungi isolated from medicinal plants are considered as an attractive source of novel bioactive compounds (Tan \& Zou, 2001; Strobel et al., 2004; Zhang et al., 2006; Kumar et al., 2014). According to Strobel and Daisy (2003), the endophytic fungi, which were isolated from Taxus brevifolia, have the ability to produce active compounds such as paclitaxel or taxol, which is beneficial as an anticancer agent.

Various types of plants can be used as the hosts for endophytic fungi. As mentioned above, an endophytic fungus from medicinal plants is a source of beneficial secondary metabolites. It also can produce bioactive compounds which are potential as materials for producing modern medicine or agrochemical 
application (Widowati et al., 2016; Praptiwi et al., 2018). One of the plant species which can be a host for endophytic fungi is M. oleifera Lam. It is a small, fast-growing, deciduous, or evergreen tree which can grow up to 10-12 m in height (Roloff et al., 2009). This study was conducted to investigate the abundance and diversity of endophytic fungi inhabiting $M$. oleifera collected from Lombok island, West Nusa Tenggara Province, Indonesia.

\section{Materials and Methods}

Plant Materials. The plant materials of Moringa oleifera was collected from Lombok island, West Nusa Tenggara Province, Indonesia, on 11 April 2019 (Table 1). Plant samples consist of fresh material and healthy living tissue of $M$. oleifera leaves, petioles, and stems. All fresh samples were marked, packed carefully, and then transferred to the laboratory for isolation purposes within less than $72 \mathrm{~h}$.

Table 1. List of Moringa oleifera Lam. samples collected from Lombok island, West Nusa Tenggara Province

\begin{tabular}{|c|c|c|c|c|c|c|}
\hline No & $\begin{array}{c}\text { Sample } \\
\text { Code }\end{array}$ & $\begin{array}{c}\text { Sample } \\
\text { Description }\end{array}$ & $\begin{array}{c}\text { Sample } \\
\text { Collector }\end{array}$ & $\begin{array}{c}\text { Sampling } \\
\text { Site }\end{array}$ & $\begin{array}{c}\text { GPS } \\
\text { Coordinate }\end{array}$ & $\begin{array}{c}\text { Altitude } \\
\text { (m.alt) }\end{array}$ \\
\hline 1 & ML 01 & $\begin{array}{l}\text { Leaves, } \\
\text { petioles, } \\
\text { and stems } \\
\text { of } M \text {. } \\
\text { oleifera }\end{array}$ & $\begin{array}{c}\text { MI \& } \\
I^{*}\end{array}$ & $\begin{array}{l}\text { Narmada } \\
\text { park, } \\
\text { Lembuah } \\
\text { village, } \\
\text { Narmada } \\
\text { sub } \\
\text { regency, } \\
\text { West } \\
\text { Lombok } \\
\text { regency }\end{array}$ & $\begin{array}{l}\mathrm{S} \\
08^{\circ} 35^{\prime} 41.8 \\
" \mathrm{E} \\
116^{\circ} 12^{\prime} 15 . \\
1^{\prime \prime}\end{array}$ & 121 \\
\hline 2 & ML 02 & $\begin{array}{l}\text { Leaves, } \\
\text { petioles, } \\
\text { and stems } \\
\text { of } M \text {. } \\
\text { oleifera }\end{array}$ & $\begin{array}{l}\text { MI \& } \\
\text { IR* }\end{array}$ & $\begin{array}{l}\text { Tragtag } \\
\text { village, } \\
\text { Lingsar } \\
\text { sub } \\
\text { regency, } \\
\text { West } \\
\text { Lombok } \\
\text { regency }\end{array}$ & $\begin{array}{l}\mathrm{S} \\
08^{\circ} 34^{\prime} 21^{\prime \prime} \\
\mathrm{E} \\
116^{\circ} 11^{\prime} 5.6 \\
"\end{array}$ & 134 \\
\hline 3 & ML 03 & $\begin{array}{l}\text { Leaves, } \\
\text { petioles, } \\
\text { and stems } \\
\text { of } M \text {. } \\
\text { oleifera }\end{array}$ & $\begin{array}{l}\text { MI \& } \\
\text { IR* }\end{array}$ & $\begin{array}{l}\text { Selat } \\
\text { village, } \\
\text { Lingsar } \\
\text { sub } \\
\text { regency, } \\
\text { West } \\
\text { Lombok } \\
\text { regency }\end{array}$ & $\begin{array}{l}\mathrm{S} \\
08^{\circ} 34^{\prime} 53.2 \\
" \quad \mathrm{E} \\
116^{\circ} 12^{\prime} 40 . \\
4^{\prime \prime}\end{array}$ & 174 \\
\hline $\begin{array}{l}\mathrm{N} \\
\mathrm{R}\end{array}$ & $d$ & & $\operatorname{mad}$ & Ilyas & and & riati \\
\hline
\end{tabular}

\section{Fungal Isolation.}

The fungal isolation was carried out based on the surface sterilization method with slight modification (Ilyas et al., 2019). Plant samples were sterilized by immersing in $70 \%$ ethanol for $1 \mathrm{~min}$, and then sterilized with $1 \%$ sodium hypochlorite $(\mathrm{NaOCl})$ solution for $2 \mathrm{~min}$. Samples were rinsed twice in sterile distilled water and put into sterile paper towels for 3-4 $\mathrm{h}$ to remove water from the surface. Afterward, samples aseptically cut into small segments about $5 \mathrm{~mm}^{2}$ and then placed onto a $90-\mathrm{mm}$ Petri dish containing malt extract agar (MEA). On each MEA plate, 7 small segments of leaves, 6 segments of petioles, and 5 segments of stem samples were randomly placed. Each plant sample was made as many as 3 replicates. The culture was then incubated at $27^{\circ} \mathrm{C}$ for 2 weeks. The endophytic fungi growing out from samples were isolated and purified by transferring onto a 60-mm Petri dish containing potato dextrose agar (PDA). The purified fungal strains were then selected for working and backup collections. The backup collections were stored based on a freezing method at $-80^{\circ} \mathrm{C}$ using $10 \%(\mathrm{v} / \mathrm{v})$ glycerol and $5 \%(\mathrm{~g} / \mathrm{v})$ trehalose as a cryoprotectant (Kanti et al., 2018).

\section{Molecular identification.}

The molecular identification was based on the DNA sequence analysis of an internal transcribed spacer (ITS1 and ITS2) of rDNA regions, including 5.8S rRNA. The fungal genomic DNA was isolated using Nucleon PhytoPure (GE Healthcare) according to the manufacturer's instruction. DNA amplification of the ITS rDNA region was performed by polymerase chain reaction (PCR). PCR amplification was performed in a $25-\mu \mathrm{L}$ reaction mixture containing $10 \mu \mathrm{L}$ of distilled water, $12.5 \mu \mathrm{L}$ of GoTaq Green Master Mix (Promega), $0.5 \mu \mathrm{L}$ of DMSO, $0.5 \mu \mathrm{L}$ of each primer $(10 \mathrm{pmol})$, and $1 \mu \mathrm{L}(5-10 \mathrm{ng})$ of genomic DNA as a template. The primer set of ITS4 (5'-TCC TCC GCT TAT TGA TAT GC$\left.3^{\prime}\right)$ and ITS5 (5'-GGA AGT AAA AGT CGT AAC AAG G-3') was used to amplify approximately 550 nucleotides from ITS1 and ITS 2 including 5.8S rDNA (White et al., 1990). Amplification was performed in a TaKaRa PCR Thermal Cycler P650 (TAKARA BIO Inc.) under the following conditions: initial denaturation at $95{ }^{\circ} \mathrm{C}$ for 3 min, 30 cycles at $95^{\circ} \mathrm{C}$ for $30 \mathrm{~s}, 55^{\circ} \mathrm{C}$ for $30 \mathrm{~s}$, and $72{ }^{\circ} \mathrm{C}$ for $1 \mathrm{~min}$. The PCR products were then subjected to purification and sequence analysis.

\section{Data Analysis.}

The occurrence of fungal endophyte in the plant sample part was measured by the colonization frequency (CF) or colonization rate $(\mathrm{CR}) . \mathrm{CF}$ is the number of plant segments 
with endophytic fungi colonization divided by the total number of all incubated segments (Yuan et al., 2010). CF in the plant part is the average $\mathrm{CF}$ of each plant segment. $\mathrm{CF}$ in the plant is the average $\mathrm{CF}$ of all segments from one plant sample. $\mathrm{CF}, \mathrm{CF}$ in the plant part, and $\mathrm{CF}$ in the plant are expressed in percentage.

Meanwhile, the presence of each fungal endophyte species was measured by the isolation frequency (IF). IF is the number of plant fragments from which the fungus was isolated divided by the total number of seeded fragments (Ragazzi et al., 2001). IF is expressed in percentage. The results of the data obtained were then analyzed using a descriptive method.

\section{Phylogenetic Analysis.}

The raw sequence data were edited using SeqMan Pro version 7.1.0 (44.1) in the DNASTAR laser gene core suite software (DNASTAR Inc., Madison, WI, USA). The assembled sequences were aligned against the National Center for Biotechnology Information (NCBI) database (http://www.ncbi.nlm.nlh.gov/) using the MUSCLE (Edgar, 2004) in MEGA version 7 program (Kumar et al., 2016). The phylogenetic analyses of sequence data were performed based on the Neighbor-Joining (NJ) method (Saito \& Nei, 1987) using the Kimura 2-parameter $+G+I$ model as the best evolutionary model in MEGA 7 (Kimura, 1980). The reliability of each branch was evaluated by bootstrapping with 1000 resampling in NJ (Felsenstein, 1985).

\section{Results}

Colonization and Isolation Frequency of Endophytic Fungi.

In total, 63 leaf, 54 petiole, and 45 stem segments from three plant samples of $M$. oleifera were used and analyzed in this study. The fungal endophytes started growing from plant tissues after $5-7 \mathrm{~d}$ incubation at $27{ }^{\circ} \mathrm{C}$ (Figure 1). The occurrence of endophytes in each plant part or segment was then calculated based on the colonization frequency (CF) equation, and the results are depicted in Table 2.

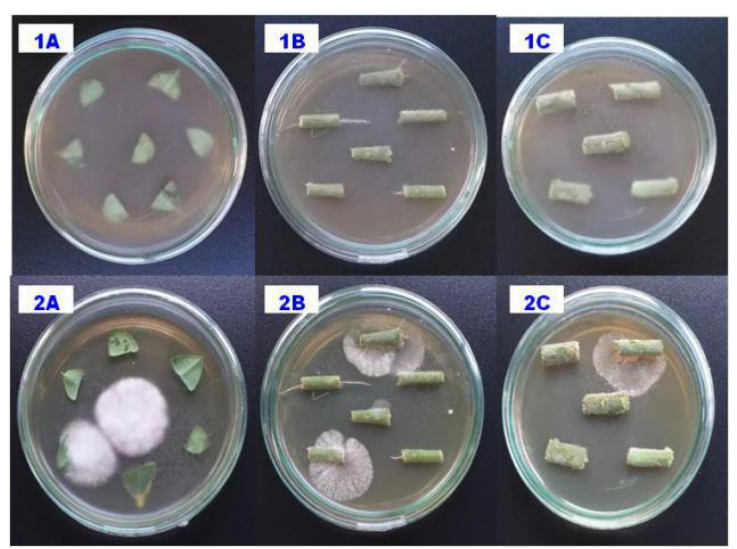

Figure 1. Fungal endophytes associated with Moringa oleifera Lam. isolation based on surface sterilization method: Leaves samples (1A), petioles samples (1B), and stems samples (1C). Fungal mycelia were grown from samples on MEA media after 5-7 d incubation at $27^{\circ} \mathrm{C}(2 \mathrm{~A}, 2 \mathrm{~B}, 2 \mathrm{C})$.

Table 2. Percentage of colonization frequency (CF) of the endophytic fungi inhabiting Moringa oleifera Lam. collected from Lombok island, West Nusa Tenggara Province

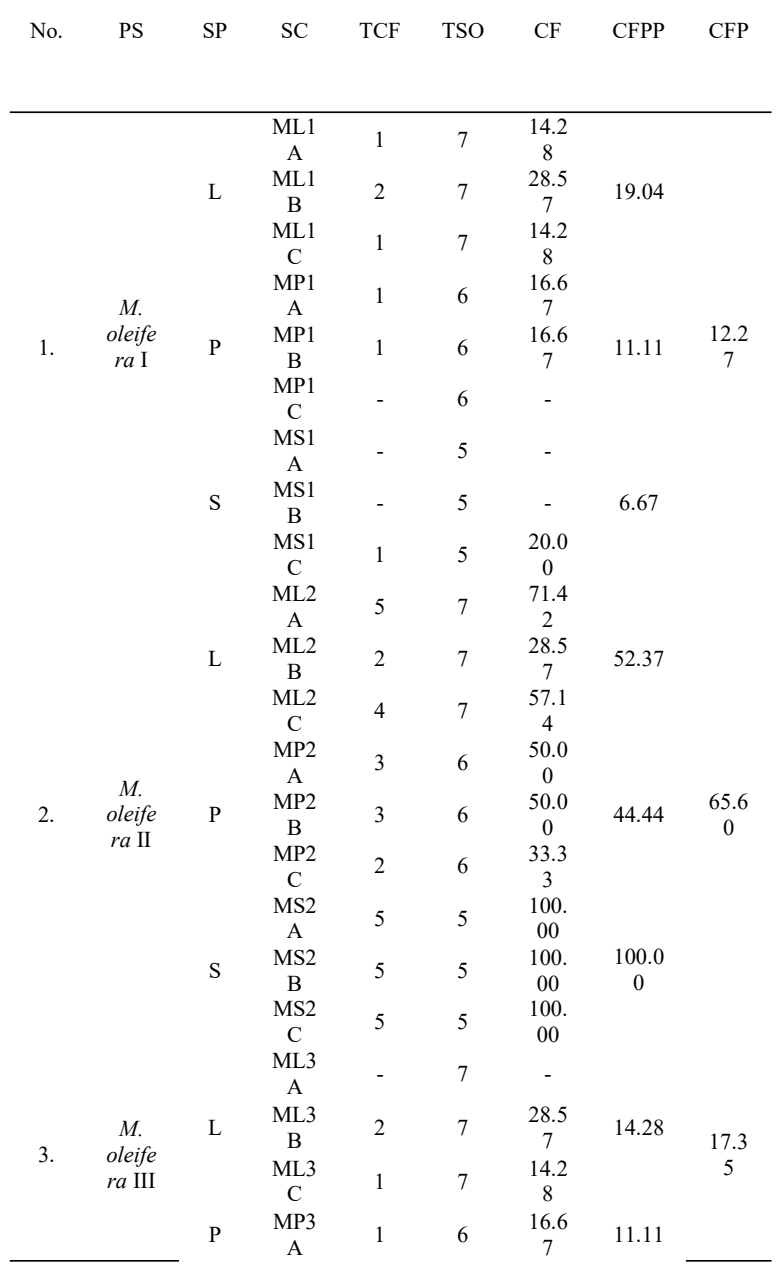




$$
\begin{array}{cccccc} 
& \text { MP3 } & 1 & 6 & 16.6 & \\
\text { B } & 1 & & 7 & \\
\text { MP3 } & & & - & \\
\text { C } & - & 6 & & \\
\text { MS3 } & & & 20.0 & \\
\text { A } & 1 & 5 & 0 & \\
\text { S } 3 & & & 40.0 & 26.67 \\
\text { B } & 2 & 5 & 0 & \\
\text { MS3 } & & & 20.0 & \\
\text { C } & 1 & 5 & 0 &
\end{array}
$$

$P S$ plant sample, $S P$ sample part, $S C$ sample code, $T C F$ total colony formed, TSO total segment observed, $C F$ colonization frequency, CFPP colonization frequency in plant part, $C F P$ colonization frequency in plant, $L$ leaf, $P$ petiole, $S$ stem

Based on the colonization frequency (CF) results, the highest amount of endophytic fungi was from the leaves and petioles, while the least amount of endophytic fungi was from the stems part of $M$. oleifera. Further analysis of fungal endophyte occurrence based on fungal diversity in each plant parts can be seen in Table 3.

Table 3. Percentage of isolation frequency (IF) fungal endophytes inhabiting Moringa oleifera Lam. from Lombok Island, West Nusa Tenggara

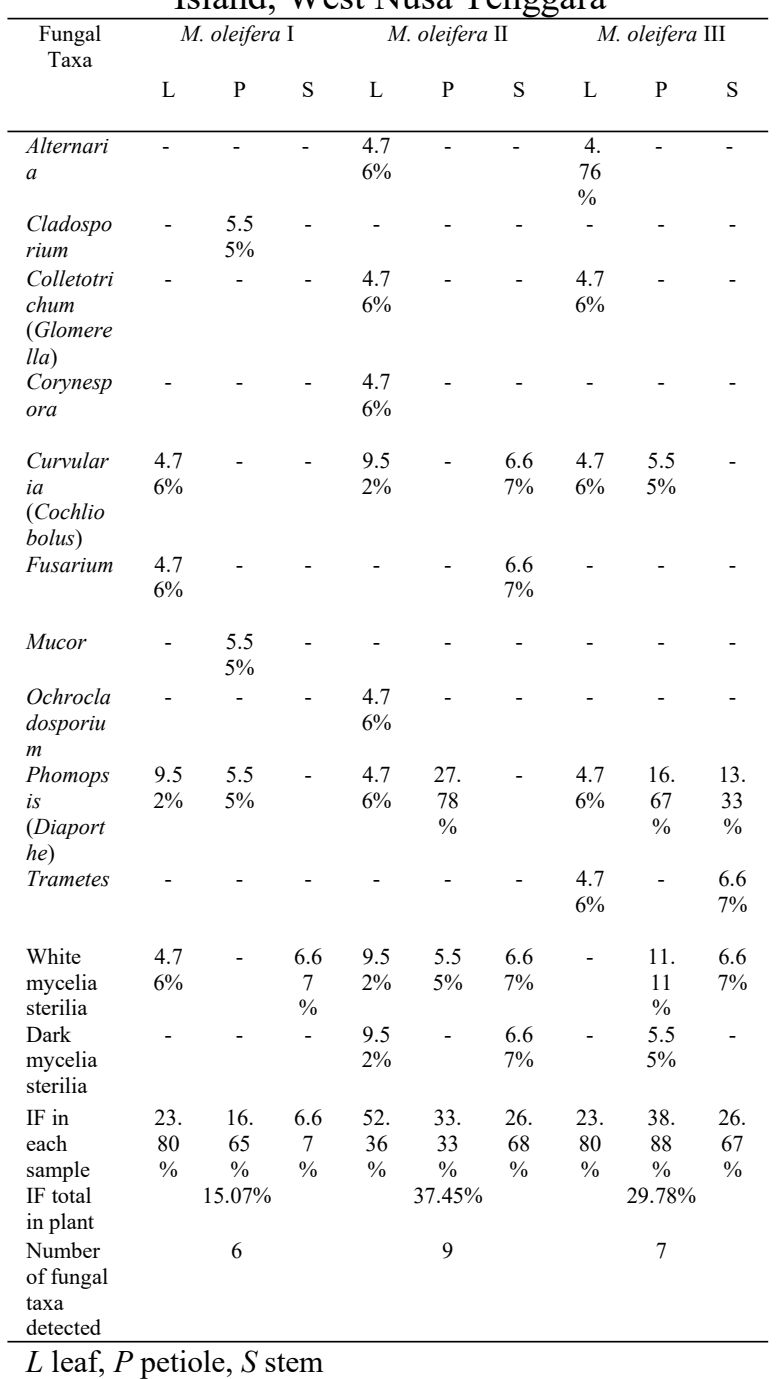

\section{Molecular Identification}

Based on molecular analysis, 46 selected endophytic fungi strains could be identified as Alternaria, Cladosporium, Colletotrichum (Glomerella), Corynespora, Curvularia (Cochliobolus), Fusarium, Mucor, Ochrocladosporium, Phomopsis (Diaporthe), and Trametes. Representatives of each fungal taxa were grown on PDA media as shown in Figure 2.

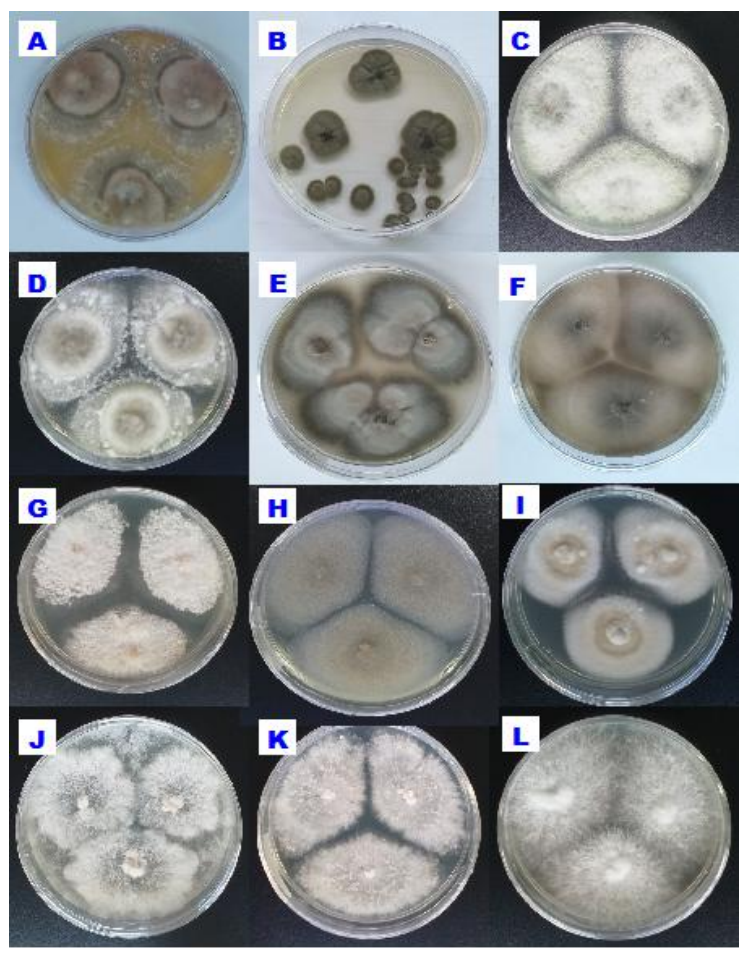

Figure 2. Macroscopic view of representatives fungal endophyte inhabiting $M$. oleifera from Lombok island, West Nusa Tenggara Province on PDA media, 7-10 d incubation at $\mathrm{T} 27^{\circ} \mathrm{C}$ : (A) Alternaria ML2CL-1 (B) Cladosporium ML1BP-1 (C) Colletotrichum (Glomerella) ML3CL-1 (D) Corynespora ML2AL-2 (E) Curvularia (Cochliobolus) ML2CL-4 Curvularia ML3BL-2 (G) Fusarium ML2BS$1 \quad(\mathrm{H}) \quad$ Mucor ML1AP-1 Ochrocladosporium ML2AL-5 (J) Phomopsis (Diaporthe) ML1CL-2 (K) Phomopsis ML2BP-2 and (L) Trametes ML3AL-1.

\section{Phylogenetic Analysis}

The phylogenetic analysis was conducted with the highest frequency of occurrence of endophytic fungi, namely Curvularia (Cochliobolus) and Phomopsis (Diaporthe). Based on the phylogenetic tree generated from the NJ analysis, the sequence of Curvularia sp. ML2CL-4 isolated from the leaf of M. oleifera 
from Lombok island, West Nusa Tenggara, Indonesia nested in the same clade with $C$. geniculata strain CBS 187.50 (KJ909781), $C$. soli CBS 222.96 (KY905679), and $C$. senegalensis CBS 149.71 (HG779001) with $79 \%$ bootstrap value (Figure 3 ). The NJ tree of Curvularia species also showed that the sequence of Curvularia sp. ML3BL-2 isolated from the leaf of $M$. oleifera nested in the same clade with C. verruculosa strain CPC 28809 (MF490824), C. verruculosa strain CBS 149.63 (HF934909), Cochliobolus verruculosus strain ZTY98400 (HM053661), and $C$. verruculosus strain ZX991074 (HM053660) with 100\% BS (Figure 3).

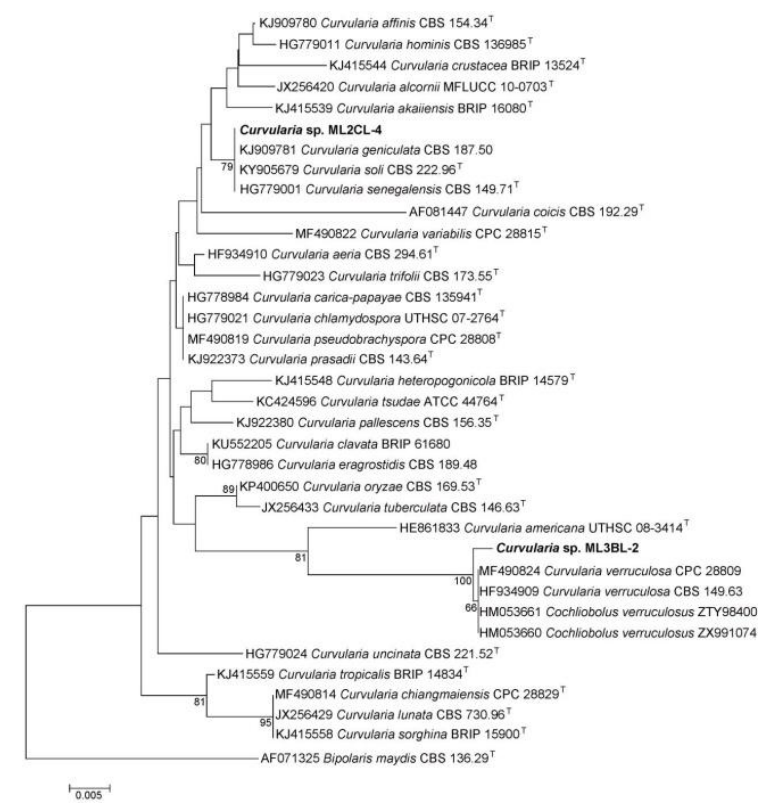

Figure 3. Neighbor-Joining (NJ) tree based on Curvularia spp. ITS sequences. Bootstrap values above $50 \%$ are recorded at the nodes (1000 replicates).

The NJ tree showed that the sequence of Diaporthe sp. ML2BP-2 isolated from petiole of M. oleifera from Lombok island, West Nusa Tenggara, Indonesia nested in the same clade with D. perseae strain ASHM300 (MK111099), D. perseae strain CBS 151.73 (KC343173), and D. phoenicicola strain SM30 (MN651492) with bootstrap value 99\% (Figure 4). The sequence of Diaporthe sp. ML1CL-2 nested the same clade with $D$. melonis strain CBS 507.78 (KC343142) with $87 \%$ BS (Figure 4).

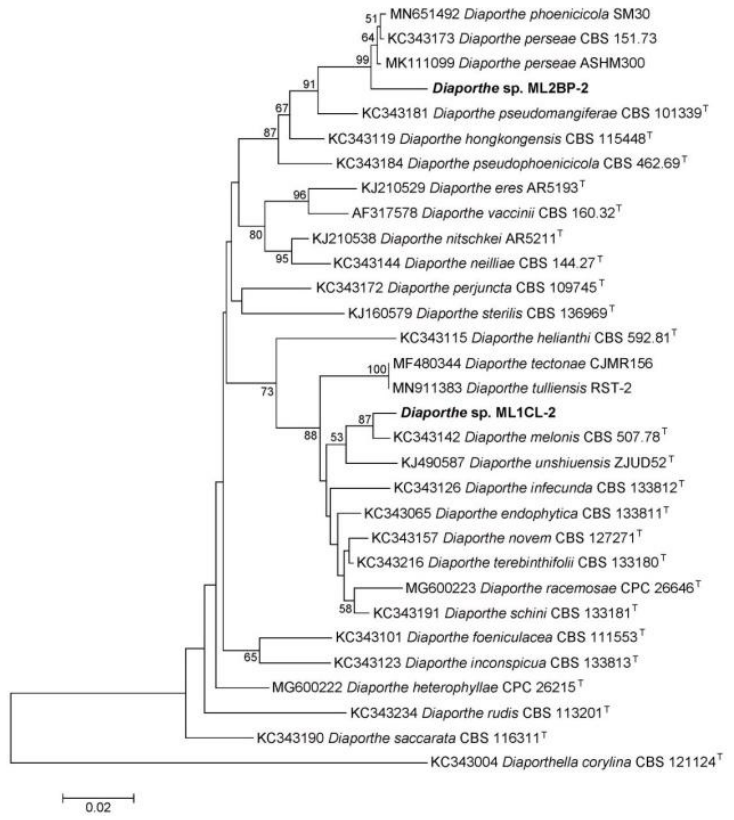

Figure 4. Neighbor-Joining (NJ) tree based on Diaporthe spp. ITS sequences. Bootstrap values above $50 \%$ are recorded at the nodes (1000 replicates).

\section{Discussion}

A total of 46 strains of endophytic fungi were isolated from 3 samples of Moringa oleifera collected from Lombok island, West Nusa Tenggara Province, consisting of 9 strains from $M$. oleifera sample I, 21 strains from M. oleifera sample II, and 16 strains from $M$. oleifera sample III. The percentage of colonization frequency (CF) results in Table 2 shows that endophytic fungi were mostly found in the leaves and stems segments of $M$. oleifera sample II with $52.37 \%$ and $100 \%$ colonization rate. The most abundant of endophytic fungi was obtained in $M$. oleifera sample II with a total colonization rate of $65.60 \%$. A previous study conducted by Dhanalakshmi et al. (2013) reported that CF of endophytic fungi from Moringa leaves was $66.6 \%$, while that in the stems sample was $25 \%$.

Based on the isolation frequency (IF) from 3 different samples of $M$. oleifera (Table 3 ), a total of 10 fungal taxa were found. Among these, endophytic Phomopsis (Diaporthe) showed the highest IF at $27.78 \%$ in the petiole of sample II, and high IF at $16.67 \%$ in the petiole of sample III. Endophytic Phomopsis was also found in almost all of the three samples, except in stem samples of I and II. 
Besides endophytic Phomopsis, endophytic fungi Curvularia (Cochliobolus) were the most frequently obtained in the plant part of $M$. oleifera sample. In general, the highest total IF was found in sample II at $37.45 \%$. Moreover, M. oleifera sample II also has the highest diversity of fungal endophyte with 9 different taxa were detected. The fungal endophyte community and composition were influenced by several factors such as the host plant species and the tissue types. Several fungal endophytic isolates indicate the significant host and tissue preferences (Li et al., 2020).

The previous studies on endophytic fungi isolated from the tropical medicinal plants reported that some of the endophytic fungi which were frequently found are Alternaria, Cladosporium, Colletotrichum, Curvularia, Diaporthe (anamorph: Phomopsis), Fusarium, Guignardia (anamorph: Phyllosticta), Lasiodiplodia, Pestalotiopsis, Schizophyllum, and Xylaria (Praptiwi et al., 2016; Praptiwi et al., 2018; Ilyas et al., 2019; Praptiwi et al., 2020; Oktavia et al., 2020). Endophytic Phomopsis is the most abundant strain and often dominating the obtained strains (Praptiwi et al., 2018; Ilyas et al., 2019). The population structure and distribution pattern of the obtained endophytic fungi are mostly influenced by environmental factors variation as well as the classification and genetic background of the host plant. The habitat of the host plant is the source of environmental factors that influences the structure and composition of microbial species that colonize roots, stems, branches, and leaves. Some of those environmental factors are temperature, humidity, geographic location, and the host plant vegetation (Jia et al., 2016).

A previous study conducted by Rajeswari et al. (2014) reported that endophytic fungi from $M$. oleifera leaves, stem, flowers, and calyx samples were predominantly by Aspergillus spp. However, in this study, endophytic fungi Phomopsis and Curvularia were the most frequently obtained in the plant parts of $M$. oleifera samples. Curvularia (Cochliobolus) was commonly found as endophytes, pathogens, and saprobes associated with various plants. In the previous study, $C$. lunata was isolated from Sorghum bicolor and it is thought to be one major cause of leaf spot disease in tropical planted sorghum (Hidayat \& Ramadhani, 2019). Curvularia soli was only found on soil in Papua New Guinea (MarinFelix et al., 2017). Curvularia geniculata was commonly found in tropical regions, $C$. senegalensis and C. verruculosa (Cochliobolus verruculosus) are distributed in subtropical and tropical regions (Farr \& Rossman, 2020). The phylogenetic analysis based on the ITS rDNA sequence could not accurately identify the species of Curvularia. Therefore, glyceraldehyde-3-phosphate dehydrogenase (gapdh) and the translation elongation factor 1alpha $($ tefl- $\alpha)$ genes could be used to determine Curvularia species.

Phomopsis (Diaporthe) is also commonly found as endophytes, pathogens, and saprobes associated with diverse plants and is distributed worldwide (Gomes et al., 2013). Diaporthe perseae is isolated from leaves, fruit, and stems. Diaporthe perseae is distributed in Barbados, Malaysia, South Africa, and the Netherlands, while Diaporthe phoenicicola is found in India. Diaporthe melonis was isolated from Cucumis melo fruit in USA and soybean stem in Myanmar (Farr \& Rossman, 2020). The ITS rDNA sequences could not be able to determine the identity of Diaporthe (Phomopsis) species. Therefore, $\beta$-tubulin (tub2) and translation elongation factor $1-\alpha$ (tef1- $\alpha)$ genes are necessary to identify Diaporthe (Phomopsis) sequences accurately.

In conclusion, this study showed that leaves, petioles, and stems of $M$. oleifera have a wide diversity of endophytic fungi. Based on the percentage of colonization frequency (CF) results, the leaves and petioles have the highest amount of endophytic fungi compared to that of stems. Based on molecular identification, we identified 10 genera from 46 selected endophytic fungi isolates. Curvularia (Cochliobolus) and Phomopsis (Diaporthe) have the highest frequency of occurrence of endophytic fungi based on IF results.

\section{Acknowledgements}

This study was financially supported by the DIPA project of Research Center for BiologyLIPI in fiscal year 2019. The authors would like to express sincere gratitude to Gita Azzizah Putri and Maya Komalasari for the molecular work assistance. 


\section{References}

Aminah, S., Tezar, R., \& Muflihani, Y. (2015). Kandungan nutrisi dan sifat fungsional tanaman kelor (Moringa oleifera). Buletin Pertanian Perkotaan, 5(2), 35-44. doi: 10.29303/jstl.v6il.158

Dhanalakshmi, R., Umamaheswari, R., Sugandhi, P., \& Arvind Prasanth, D. (2013). Biodiversity of the endophytic fungi isolated from Moringa oleifera of Yercaud Hills. International Journal of Pharmaceutical Sciences and Research, 4(3), 1064-1068.

Edgar, R. C. (2004). MUSCLE: multiple sequence alligment with high accurancy and high throughput. Nucleic Acids Research, 32, 17921797. doi:10.1093/nar/gkh340

Farr, D. F., \& Rossman, A. Y. (2020). Fungal Databases, U.S. National Fungus Collections, ARS, USDA. Retrieved August 20, 2020, from https://nt.ars-grin.gov/fungaldatabases/

Felsenstein, J. (1985). Confidence limits on phylogenetic: an approach using the bootstrap. Evolution, 39, 783-791.

Fuglie, L. J. (1999). The miracle tree Moringa oleifera natural nutrition for the tropics. Dakar, SN: Church World Service.

Gomes, R. R., Glienke, C., Videira, S. I. R., \& Lombard, L. (2013). Diaporthe: a genus of endophytic, saprobic and plant pathogenic fungi. Persoonia, 31, 1-41. doi: 10.3767/003158513X666844

Hassan, F. A. G., \& Ibrahim, M. A. (2013). Moringa oleifera: Nature is most nutritious and multi-purpose tree. International Journal of Scientific and Research Publications, 3(4), 1-5.

Ilyas, M., Praptiwi, Wulansari, D., Fathoni, A., \& Agusta, A. (2019). An assemblage of fungal endophytes isolated from medicinal plants collected from Toba and Samosir, North Sumatra. IOP Conference Series: Earth and Environmental Science, 308(1), 0-10. doi: 10.1088/1755-1315/308/1/012070

Jia, M., Chen, L., Xin, H-L., Zheng, C-J., Rahman, K., Han, T., \& Qin, L-P. (2016). A friendly relationship between endophytic fungi and medicinal plants: A systematic review. Frontiers in Microbiology, 7, 1-14. doi: 10.3389/fmicb.2016.00906

Kanti, A., Ilyas, M., Nurkanto, A., Sulistiyani, T. R., \& Meliah, S. (2018). Panduan Pengelolaan Koleksi Mikroorganisme InaCC. Jakarta: LIPI Press.

Kimura, M. (1980). A simple method for estimating evolutionary rates of base substitutions through comparative studies of nucleotide sequences. Journal of Molecular Evolution, 16(2), 111-120. doi:10.1007/BF01731581

Kumar, S., Aharwal, R. P., Shukla H., \& Rajak, R. C. (2014). Endophytic fungi: As a source of antimocrobials bioactive compounds. World Journal of Pharmacy and Pharmaceutical Sciences 3, 1179-1197.

Kumar, S., Stecher, G., \& Tamura, K. (2016). MEGA7: Molecular Evolutionary Genetics Analysis version 7.0 for bigger datasets. Molecular Biology and Evolution, 33, 18701874.

Kursia, S., Rahmad, A., \& Maria, M. N. (2018). Potensi antibakteri isolat jamur endofit dari daun kelor (Moringa oleifera Lam.). Majalah Farmasi, Sains, dan Kesehatan, 4(1), 30-33. doi: 10.33772/pharmauho.v4i1.4631

Hidayat, I. \& Ramadhani I. (2019). Phylogenetic study of Curvularia on sorghum from Indonesia based on ITS rDNA sequence. Jurnal Mikologi Indonesia, 3(2), 118-124. doi: 10.46638/jmi.v3i2.64

Li J. L., Sun X., Zheng Y., Lü P. P., Wang Y. L., \& Guo L. D. (2020). Diversity and community of culturable endophytic fungi from stems and roots of desert halophytmes in northwest China. MycoKeys, 62, 75-95. doi: 10.3897/mycokeys.62.38923

Marin-Felix, Y., Groenewald, J. Z., Cai, L., Chen Q et al. (2017). Genera of phytopathogenic fungi: GOPHY 1. Studies in Mycology, 86, 99-216. doi: 10.1016/j.simyco.2017.04.002

Oktavia, L., Evana, Ilyas, M. \& Agusta, A. (2020). The antimicrobial and antioxidant activity of endophytic fungi extract associated with Chlorantus officinalis Blume and Staurogyne elongata Kuntze. Jurnal Kimia dan Pendidikan Kimia, 5(1), 131-140. doi: 10.20961/jkpk.v5i2.40617

Praptiwi, Palupi. K., Fathoni, A., Wulansari, D., Ilyas, M., \& Agusta, A. (2016). Evaluation of antibacterial and antioxidant activity of extracts of endophytic fungi isolated from Indonesian Zingiberaceous plants. Nusantara Bioscience, 8(2), 306-311. doi:10.13057/nusbiosci/n080228

Praptiwi, Fathoni, A., Wulansari, D., Ilyas, M., Raunsai, M.M., \& Agusta, A. (2018). Evaluation of the potency of endophytic fungi extracts associated with potentially medicinal plants from Mandalika-Lombok, West Nusa Tenggara. Journal of Applied Pharmaceutical Science, 10(11), 180-190.

Praptiwi, Fathoni, A., \& Ilyas, M. (2020). Diversity of endophytic fungi from Vernonia amygdalina, their phenolic and flavonoid contents and bioactivities. Biodiversitas Journal of Biological Diversity, 21(2), 436-441. doi: 10.13057/biodiv/d210202

Ragazzi, A., Moricca, S., Capretti, P., Dellavalle, I., Mancini, F., \& Turco, E. (2001). Endophytic fungi in Quercus cerris: Isolation frequency in relation to phenological phase, tree health and the organ affected. Phytopathologia 
Mediterranea, 40(2), 165-171. doi: 10.14601/Phytopathol_Mediterr-1598

Rajeswari, S., Umamaheswari, S., Prasan, D.A., \& Rajamanikandan, K.C.P. (2014). Study of endophytic fungal community of Moringa oleifera from Omalur Region-Salem. International Journal of Pharmaceutical Science and Research, 5(11), 4887-4892.

Roloff, A., Weisgerber, H., Li, L., \& Stimm, B. (2009). Moringa oleifera Lam. Enzyklopadie der holzgewachse, Handbuchund Atlas der Dendrologie, 3(4), 1-8.

Saitou, N., \& Nei, M. (1987). The neighbor-joining method: A new method for reconstructing phylogenetic trees. Molecular Biology and Evolution, 4, 406-425. doi: 10.1093/oxfordjournals.molbev.a040454

Strobel, G. A., Daisy, B., Castillo, U., \& Harper, J. (2004). Natural products from endophytic microorganisms. Journal of Natural Products, 67, 257-268. doi:10.1021/np030397v

Strobel, G.A. \& Daisy, B. (2003). Bioprocessing for microbial endophytes and their natural products. Microbiology and Molecular Biology Reviews, 67(4), 491-502.
Tan, R.X., \& Zou W. X. (2001). Endophytes: A rich source of functional metabolites. Natural Product Reports, 18, 448-459. doi: 10.1039/B100918O

White, T. J., Bruns, T. D., Lee, S. B., \& Taylor, J. W. (1990). Amplification and direct sequencing of fungal RNA genes for phylogenetics. PCR protocols, 315-322. San Diego, US: Academic Press.

Widowati, T., Bustanussalam, Harmastini, S., \& Partomuan, S. (2016). Isolasi dan identifikasi kapang endofit dari tanaman kunyit (Curcuma longa L.) sebagai penghasil antioksidan. Biopropal Industri, 7(1), 7-16.

Yuan, Z. L., Zhang, C. L., Lin, F. C., \& Kubicek, C. P. (2010). Identity, diversity, and molecular phylogeny of the endophytic mycobiota in the roots of rare wild rice (Oryza granulate) from a nature reserve in Yunnan, China. Applied and environmental microbiology, 76(5), 1642-1652. doi:10.1128/AEM.01911-09

Zhang, H. W., Song, Y. C., \& Tan, R. X. (2006). Biology and chemistry of endophytes. Natural Product Reports, 23, 753-771. doi: 10.1039/b609472b 